\title{
Scientific Publication Management Transformation In Disruption Era
}

\author{
Untung Rahardja ${ }^{1}$, Ninda Lutfiani ${ }^{2}$, Hega Lutfilah Juniar ${ }^{3}$ \\ ${ }^{1,2,3}$ Raharja University, Jl.Jendral Sudirman No.40, Cikokol Tangerang \\ e-mail: untung@raharja.info, ninda@raharia.info, hega.lutfilah@raharia.info
}

\begin{abstract}
New innovations enter the market and create a strong disruption effect, a sign that the era of the decade that is currently happening has experienced many changes in various sectors, including economics, technology, education and politics. This study aims to examine the aspects and direction of the development of research related to the Disruption Age that affects technological developments, one of which is in the field of publication management. The approach used is a study of various definitions and model frameworks that developed around the era of disruption and management of publications as well as mapping and analysis of a number of publications. Judging from the research method, most of the research was carried out through descriptive and conceptual methods in which technological aspects became the focus of research by researchers. Disruption innovation has an impact on publication management, where publication management is increasingly developing with additional technological spices. Management of online-based scientific publications or e-journals that are able to manage scientific publication activities to create better management and publications and improve accessibility. The Ministry of Research, Technology and Higher Education targets 7,000 nationally accredited journals with six ratings. In 2018 there were 20,610 internationally published scientific works in Indonesia. The application of this online-based or e-journal scientific publication management system is able to improve the quality of the process of managing scientific journals to be more systematic and organized to achieve efficiency and improve publications to be global.
\end{abstract}

Keywords: Disruption, Innovation, Scientific Publication Management, Technology.

\section{Introduction}

The industrial revolution first occurred in the United Kingdom, precisely in 1784 where the discovery of steam engines and mechanization began to replace human work. Production machines powered by electricity were used for mass production at the end of the 19th century which marked a second revolution. Afterwards, the third revolution began to appear after the use of computer technology for manufacturing automation which began in 1970. The period that marked the decade of the rapid development of sensor technology, interconnection, and data analysis led to the idea of integrating all these technologies into various industrial fields. This idea is predicted to be a revolution. The revolution certainly also influenced the Management of Scientific Publication.

Scientific publication is a system of publications carried out through a process of research or examination of a scientific work by other experts in the same field. Scientific publication is a mandatory requirement for Bachelor students to obtain graduation, it is stated Based on the circular letter of the Ministry of Education and Culture of the Directorate General of Higher Education Number: 152 / E / T / 2012, Through this circular letter, each Indonesian Higher Education has responsibility and encouraged to improve the quality of management regarding the publication of scientific works. Head of Pusbindiklat LIPI Researcher. Permenristekdikti Number 9 Year 2018 mandates all scientific 
accredited institutions to become one under the Ministry of Research, Technology and Higher Education and all scientific journals that have been accredited by LIPI and are still valid, then they will be recognized by the Kemenristekdikti and new accreditation certificates will be issued. LIPI No. 3 of 2014 and Director General of Higher Education No. 1 of 2014 issued regulations related to accreditation of scientific periodicals, starting in 2014 and effective April 1, 2016, it was emphasized that the journal to be accredited must be published in electronic form, certainly impacting on the paradigm shift of journal managers to switch to publishing electronic journals. Not infrequently, the managers of journals, both editors and reviewers, who are accustomed to handling printed journal publications experience confusion when they have to turn to electronic journals. How to manage electronic journals properly and correctly against the authors as researchers in the field of Information Sciences at the Indonesian Institute of Sciences (LIPI) seems to be a question that is questionable. Publication of a scientific work in this case the journal basically involves many processes and roles involved, several processes are needed until a journal can be published, including starting from the submission process, initial selection, article review, revision submission, (if there is something that needs to be corrected) ), and editing until finally a scientific article can be properly published in a journal [1]. This proves that scientific publication management is also affected by disrupted changes which eventually evolved.

According to JayashreeR, good language and grammar skills are needed, as well as understanding mature knowledge in accordance with the topic of scientific work in scientific paper writing. Add additional information and facts about one side of the power of arguments to support content arguments in papers [2]. As a reference for search engines and scientific articles in writing scientific papers, this is where there are unlimited sources of information. [3]. Google Scholar is a service that is supported by Google and aims to compile articles, taking into account the completeness of the text in each article written, the author of the article, and displaying a number of references from published articles. Google Scholar is very useful in making scientific works as dividends from scientific literature [4].

Scientific Publication Management finally sets the results of accreditation assessments, which are then divided into 6 (six) ratings. After at least one publication, an increase in the results of the accreditation assessment can be done. The period of accreditation has been valid for 5 years since the last issue that was acknowledged was evaluated. Starting in 2017, the Ministry of Research and Technology launches SINTA to facilitate data collection on citations, citations and scientific journals. Rumah Jurnal Indonesia is provided by the Ministry of Research, Technology and Higher Education which is a free application journal cloud so that managers do not need to have servers, journal management applications and IT experts. Dr. Muhammad Dimyati as Director General of Research and Development of the Ministry of Research, Technology and Higher Education said that related to Online Scientific Journal Management Bureaucratic Reform. 2016 Gross Expenditure on Research and Development (GERD) of Rp. 30.78 trillion (0.25\%) per GDP [5].

\subsection{Publication Ethics}

Related to journal accreditation migration. Prof. Dr. Ir. Bambang Subiyanto, M.Sc. Directing This is because the scoring system at LIPI with the Ministry of Research, Technology and Higher Education is different where LIPI only ranks A and B while the Ministry of Research, Technology and Higher Education has 6 ranks, so the journals issued and previously accredited may not be impaired. Therefore, publication ethics is an important matter. There are three (3) ethics in publication:

Neutral, in the sense of being free from conflicts of interest in the management of scientific publications. 
Justice, giving authorship rights to those who should actually write the script. In the sense that no writer is actually not involved in making the manuscript but because it has influence, the name is included in the scriptwriter and becomes one of the authors in the text.

Honesty, which is free from plagiarism in the publication of scientific works.

In general, the line quotation is indicated by the number of times the article has been quoted by other article means, the article cited is said to have good quality [6]. The scientific code of ethics statement is a code of ethics statement for all parties involved in the process of publishing scientific journals, namely managers, editors, bestari partners and writers.

\subsection{Application for Publication Management}

During the session on the Utilization of the Portal Science and Technology Index (SINTA), Dr. Lukman, S.T., M.Hum. (Head of Sub Directorate of Scientific Journal Facilitation, Kemenristekdikti) conveyed indicators of developed countries are the highest number of publications, citations and $\mathrm{H}$ Index. The higher the level of citations in published articles, the higher the frequency of $\mathrm{H}$-Index in the article, so that it is effective in improving the quality of research papers [7]. The SINTA application which is a vehicle for data collection, mapping, measurement of publication, citations, intellectual property performance results and community service for dissemination, research performance recognition in Indonesia is dynamically launched in 2017. In order to enter Scopus which is an analytical tool, our text must have been cited by the author who was registered with Scopus. To measure the nation's achievement, the benchmark results of publications are used as references, universities / institutions, study programs / units, researchers compared to other parties. There is a comprehensive and fair standard of measurement (score) that can be accepted by many parties. A database is also needed to provide publication data for all Indonesian lecturers and researchers.

Digital Referral Garba (GARUDA) is a powerful resource platform for the discovery of scientific publications in Indonesia. Science Direct as an e-journal and indexation database has made a similar Digital Referral Garba application, managed by the Republic of Indonesia Ministry of Research, Technology and Higher Education (Kemenristekdikti). GARUDA is designed to search, index, abstract, monitor and improve the standards of scientific publications in Indonesia that are important for researchers, lecturers, students, librarians, policy makers and policy makers. It can be relied upon to use a leading scientific and technical content discovery platform, especially all of which are obtained by saving more time and accessing relevant information in a convenient and fast way [8].

\subsection{SINTA Data Flow}

Business process at SINTA is to draw data based on Scopus ID and Google Scholar IDE that are registered by the author. As well as book data, it is enough to enter the ISBN number so SINTA will automatically withdraw the book data from the National Library. Likewise, it is also possible to enter the patent number that is owned so that the patent data will automatically be taken and loaded in SINTA.

The measurement of publication performance was measured in quantity in terms of the number of indexed journal articles, proceedings, books, and editorials in Scopus and in terms of quality in terms of the number of Scopus and GS citations.

\subsection{Accreditation Submission Mechanism}

Prof. Dr. Istadi, S.T., M.T. submit Guidelines for Scientific Journal Accreditation along with the requirements of the Scientific Journal. Of course, it must clearly contain science, technology, or art based on the results of research, engineering, and studies that contain original or non-plagiaristic findings or thoughts, the editorial board and partners are best qualified journals, using Indonesian or the official UN language, maintaining consistency of writing style and appearance format, managed and published electronically, published according to schedule, having EISSN and DOI. 
The theoretical foundation is a theory that serves to explain the scientific work to be studied and the average is mostly used to provide temporary answers to the formulation of the problem presented in the relevant hypothesis. The theory used as a source is not only the opinions or ideas of previous writers or writers, but theories of truth and legitimacy are well tested [9]. Scientific journals with a value of $>30$ will be grouped in six accreditation ratings [10].

The research was conducted by Andi Murniati. (2012) entitled "Utilization of e-journal and ebook by students in the Faculty of Tarbiyah and Teacher Training at UIN SUSK Riau". This research was conducted to determine the utilization of e-journals and e-books, as well as the impact obtained after the use of e-journals and e-books among students in the Tarbiyah Faculty and UIN SUSKA RIAU Teacher Training [11].

\section{Research Method}

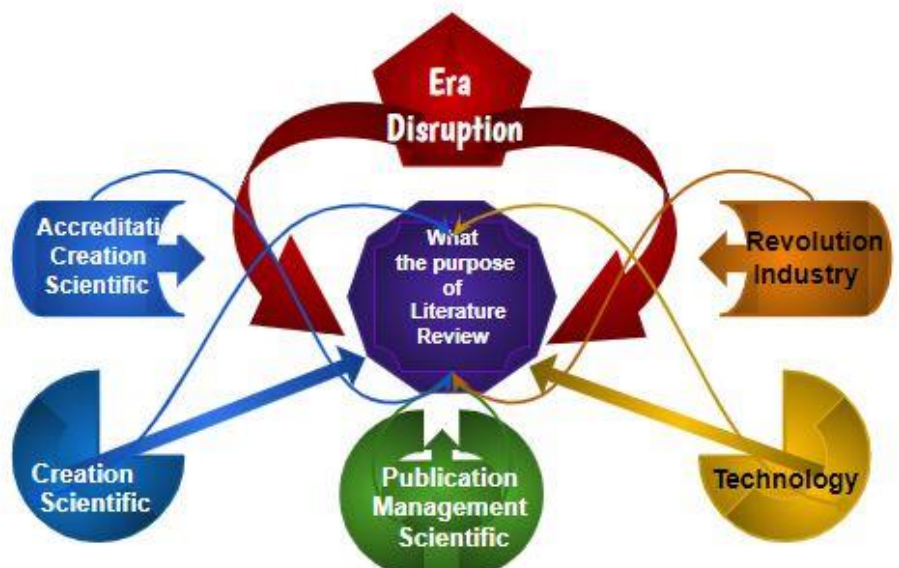

Figure 1. Literature Review

This study uses a Literature Review method, namely: a method in research where data collection from previous studies is then examined where it aims to form a theoretical basis of the material being studied. The research data uses secondary data such as literature, journal references and research results. One more method used in this study is; qualitative method. This method is also a method that describes the theories, findings, and other research material obtained from reference materials to be used as the basis of research activities to develop a clear framework of the formulation of the problem to be studied.

\subsection{The era of disruption}

It can be said, disruptive is an innovation in the form of technology that is able to threaten the existence of a market that already exists due to the creation of new markets and ultimately will replace the old market or old technology. Usually by creating different types of consumers on new markets and lowering prices on the old market. This disruptive innovation can rise in developing products or services in an unexpected way [12].

The disruption era occurs when a new innovation enters the market and creates a disruption effect that is strong enough to change the previous market structure. The internet of things and the digital world cannot be separated from the changes that occur in the current era of globalization. With the technology that continues to grow and become more sophisticated, it facilitates new innovations to be born and replace old ways that are less effective and efficient. These new innovations are also required to be able to follow the needs of the community and developments that continue to move forward. Innovation is a research, development activity, aimed at developing 
practical application of new scientific values and contexts, or new ways to apply existing science and technology into products or production processes.

\subsection{Industrial Revolution}

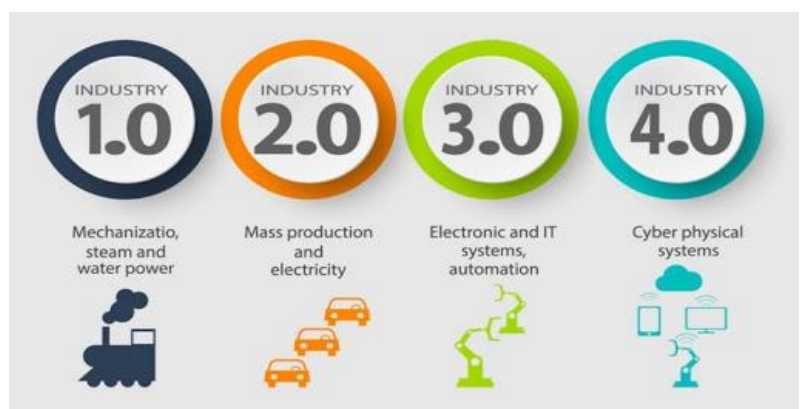

Figure 2. Industrial Revolution

The industrial revolution is a fundamental change in the way of life and human work processes. It first appeared in the 1750s, this is what is commonly called the Industrial Revolution 1.0. The Industrial Revolution 1.0 lasted between 1750-1850. At that time there was a massive change in the fields of agriculture, manufacturing, mining, transportation and technology and had a profound impact on the social, economic and cultural conditions in the world. The 1.0 generation revolution gave birth to history when human and animal power was replaced by the appearance of the engine. One of them was the emergence of a steam engine in the 18th century.

The Industrial Revolution 2.0, also known as the Technology Revolution was a rapid phase of industrialization in the late 19th and early 20th centuries. The Industrial Revolution 1.0, which ended in the mid-1800s, was punctuated by a slowdown in macro discovery before the Industrial Revolution 2.0 emerged in 1870. The generation 2.0 industrial revolution was marked by the emergence of electric power plants and combustion chambers. This discovery triggered the emergence of telephones, cars, airplanes, etc. that significantly changed the face of the world. The emergence of digital technology and the internet marked the start of the Industrial Revolution 3.0.

In addition to carrying the present, the 3.0 industrial revolution changes the pattern of relations and communication of contemporary society. Business practices also have to change or not to be swallowed by the times. However, the third industrial revolution also has a side that is worth watching out for. Technology makes factories and industrial machines prefer machines to humans. Then in the generation 4.0 industrial revolution, humans have discovered new patterns when disruptive technology (disruptive technology) is present so quickly and threatens the existence of incumbent companies. History has noted that the industrial revolution has claimed many lives with the death of giant companies.

The production process system depends on devices that communicate autonomously with each other and this technology becomes a value chain and the future can make decentralized decisions based on self-organization mechanisms in the presence of virtual copies of the physical world monitoring system is also called the fourth industrial revolution which also defines the Revolution Industry 4.0 [13] [14].

The 4th Generation Industrial Revolution (Industry 4.0) which increased innovation was rapidly led by Germany with a transformation [15] [16] [17].

\subsection{Technology}

In 1937, came the opinion that was triggered by a sociologist from America, named Read Bain. Bain (1937) said that technology basically includes all tools, machines, tools, apparatus, 
weapons, housing, clothing, transporting devices and communications, as well as skills, where this allows us as human beings to produce all that. In addition, one of the largest encyclopedia sites, Wikipedia, says that technology is a reference to a collection of techniques that cover many things. Furthermore, it is stated that technology is an entity, object or non-object created in an integrated manner through the process of creation and creation and thought to achieve certain values. Djoyohadikusumo (1994) defines the notion of technology as a field that is closely related to science and engineering or engineering science. It can be concluded that basically technology can be called having two dimensions, namely the engineering dimension and also the science dimension. The two dimensions will be bound together during the development and creation of a technology, and cannot be separated. No doubt, technology is the biggest role of change in the implementation of IImia Publication Management which has now been disrupted. Of course in the Disruption Era like now, it seems very impossible if the Scientific Publication Management is not affected by disruption. However, the benefits and conveniences that are obtained are certainly the main points for us who certainly enjoy the effects of the Era shift which also hit IImia Publication Management.

\subsection{Scientific Publication Management}

Publication management is an activity in carrying out functions; planning, organizing, coordinating, managing personnel, and supervising activities in the publication of decirmation on the results of research center studies. Publication activities serve as a means of communication between researchers and the user community, academics and the general public. Physically the form of publication of research results can take the form of: Scientific Journal, Monograph Book, Proceedings of Research Results, Reference Book, and results of research that is digitally disseminated, published in national and international scientific magazines. The indicator of the success of the management of the publication of research results at the study center is basically indicated by the large contribution to the advancement of science, technology and art. The indicators mentioned are difficult to measure success, so easy measurable indicators are needed, evaluated and developed in the future. Indicators of the successful publication of research results at the study center can be mentioned:

1. The number of publications in the form of journals, proceedings of research results seminars, monograph books, research books, results of digitally desirmilized research, are published in scientific magazines.

2. The level of journal accreditation managed by the study center.

3. The number of scientific publications of study centers that are utilized by the user community, and

4. Level of response to utilization of publications The success of the management of the publication of research results at the study center is not only interpreted as a support for its contribution to achieving the university's mission as a research university, but more than that it is intended for community use. The management holder at the study center level turns out to have a very strategic role in determine policies in achieving the successful publication of research results. Each study center has diversity in managing the implementation of scientific publications, resulting in a different quality of scientific publications. The results of the study show that most study centers have published research results with moderate standards, only a small number of study centers have published research results with good standards. This condition will continue to change along with the development of applicable standards supported by university policies.

Previous research has been conducted on online surveys and other related research. In developing and efforts to perfect this e-journal system, a literature review is needed as one of the methods of research that will be carried out. Other research related to Scientific Publication Management can be seen from the points including:

1. "Describes the follow-up in scientific activities in the form of research or a reference study as a tool to disseminate a scientific work on the research conducted by Syamsul Alam. (2015) 
entitled "Writing Scientific Articles for Scientific Publication Through Journals" [18].

2. "Explaining a PESSTA+ system so that it makes it easier for journal validation for students and college students to facilitate obtaining a valid value as a graduation requirement for raharja colleges" In the research conducted by Indri Handayani, Qurotul Aini, Fanni Oktaviani. (2016) entitled "IMPLEMENTATION OF JOURNAL VALIDATION SYSTEM IN STATE + AS ASSESSMENT OF SCIENTIFIC ARTICLES IN SUPPORTING ACADEMIC CIVILITY ACTIVITIES" [19].

3. "Discussing about an e-journal system that can automate the delivery of scientific articles so that the management of e-journal, the process can be carried out quickly and efficiently" In the research conducted by Indri Handayani. (2015) entitled "Utilization of the MeMe System (iLearning Media) and Rinfo (Raharja. Info) in the application of the E-Journal System in CCIT Journal at Raharja Higher Education" [20].

4. "For an e-journal system that provides better and more accessible services to all contributors to the Telkomnika journal at STMIK General Achmad Yani Yogyakarta" In a study conducted by Multi Baihaqi and Ahmad Hanafi (2015) entitled "DESIGN AND MAKING E -JOURNAL USING OPEN JOURNAL SYSTEM IN STMIK GENERAL OF ACHMAD YANI YOGYAKARTA "[21].

We can conclude from the four previous studies, the importance of management of scientific publications in the current era of disruption is worthy of attention and continues to be developed. The existence of online-based scientific publication management or e-journals that are able to manage scientific publication activities to create better management and publications and improve accessibility is certainly a means for researchers to develop. This is certainly well supported by the government to develop the quality of education.

\subsection{Scientific Work}

Scientific Work is a written and published report that describes the results of research or assessment that has been carried out by a person or a team by fulfilling scientific principles and ethics that are confirmed and adhered to by the scientific community. According to Drs. Totok Djuroto and Dr. Bambang Supriyadi, Scientific work is a series of writing activities based on the results of research, which are systematically based on scientific methods, to obtain scientific answers to problems that have arisen before. Whereas according to Jones, from the understanding of scientific works is divided into two, namely Scientific Work and Popular Scientific Work. Scientific work is a scientific essay aimed at certain or professional societies that are usually of high scientific nature. While popular scientific works are scientific essays aimed at the general public. In the process of writing scientific papers, the author will make a library or reference list that is used to include sources of information from previous researchers used in scientific works written by the author [22]. In universities, especially undergraduate level, students are trained to produce scientific works such as papers, lab reports, journals and (final assignments).

\subsection{Accreditation of Scientific Work}

To strengthen its findings in scientific work made, give awards to previous writers, inform readers of scientific research that has been carried out by previous scientists, explain concepts and explain theories, show other works or references, etc. A writer quotes a scientific paper on previous researchers [23 ] As a manifestation of official recognition of the quality assurance of scientific journals through the reasoning assessment of script screening, management feasibility, and timely publication, journal accreditation is needed. The Minister of Technology Research and Higher Education issued Permenristekdikti Number 9 Year 2018 concerning Accreditation of Scientific Journals conducted to meet the needs of accredited national scientific journals and bureaucratic reform of national scientific journal accreditation services, Accreditation Rankings are divided into 6 where grades 85 to 100; Rating 2 gets a minimum score of 70; Rank 3 with a minimum value of 60 ; Rating 4 with a minimum value of 50; Rank 5 with a minimum value of 40; and Rank 6 with a minimum 
value of 30. Minister of Technology Research and Higher Education number 9 of 2018 issued a regulation concerning Accreditation of Scientific Journals, an important part in efforts to reform the bureaucracy of quality assurance in the management of national scientific journals. The policy in the form of the obligation to publish in scientific journals has resulted in a drastic increase in demand for ISSN to PDII-LIPI which reached more than 50 thousand, including more than 25 thousand scientific journals published electronically. Before the issuance of the Permenristekdikti, the authority for accreditation was in two institutions, namely in the Kemenristekdikti for journals published by professional associations and universities, and in LIPI for journals published by R \& D institutions. The accreditation process is only carried out twice a year. With the changing of the regulation, it is necessary to adjust to the journal manuals and accreditation systems that have been carried out through the National Journal Accreditation portal. Accreditation status is determined based on Total Accreditation Value. Accreditation Results The scientific journal determined by the Accreditation Team is used by the Assessment Team of Functional Credit Numbers in assessing the substance of the article and contained in the science and technology indexing system. A scientific journal is declared to be accredited Rank 2 if at least obtains a total value of 70 (management and substance), with a value of at least 26 [17]. An accredited scientific journal ranked 2 to 6 if indexed in reputable international indexers such as scopus or web of science (SCI / SCIE) has the right to get a Rank 1 Accredited status [18].

\section{Results And Analysis}

The Disrupted Era encourages all things to develop and face the changing times which are spelled out so rapidly. Information and communication technology that continues to evolve has an impact on the management and publishing of scientific journals which were originally printed with a long process, now becoming faster with electronic processes. Delivery, editing, review, and publication of scientific papers is carried out in an application system called the electronic scientific journal (e-journal). One of them, namely Aptisi Transactions on Management (ATM). Is a scientific journal published, by APTISI (Association of Indonesian Private Universities), in order to facilitate scientific journals the results of the Academic Community in the fields of information technology, communication and management in the face of the digital era in Indonesia. The scientific journal is the field of ATM information systems and information technology containing writings on pure scientific research and applied in the field of information systems and information technology and the application of science in other related fields. ATM has obtained a number of official ISSN LIPI (Indonesian Institute of Sciences), with numbers 2622-6804 (online) ISSN and ISSN 2622-6812 (print). Semi-annual ATM Rising (2 times a year, starting January and July). With a system like this, the process of indexing and scientific impact or citation of a writing will be known quickly so that the benefits of a scientific paper can be felt and monitored immediately.

The change in paradigm from printed scientific journals to electronics must be followed by development by both writers and publishers in Indonesia so that the resulting work can be immediately known and known to the public both nationally and internationally. The paradigm also needs to be followed by supporting regulations, in addition to the availability of awards and sanctions, from policy makers related to quality scientific journals through the accreditation process of journals and scientific articles in it through the process of assessing credit numbers for researchers and lecturers. At present, several scientific journals in Indonesia have not yet realized the importance of indexing as a way of global dissemination. To improve the quality and reputation of scientific journals, the current accreditation guidelines for scientific journals need to be adjusted. Scientific journal publishers must maintain and improve the quality of their publications and make their journals a vehicle for scientific communication between researchers, academics, and the user community to achieve goals, namely to develop knowledge and meet development needs in Indonesia.

\section{Conclusion}

In reality the Disruption Age brought so many changes. Changes in terms of technology are 
very visible. Factors that encourage change, including the dynamics and complexity of the external environment such as technological developments are very fast in various parts of the world. However, the very severe effects of Disruption certainly have an impact on the publication of scientific works. Where currently the Scientific Publication Management has received a technological spice which is certainly of a good impact, where the delivery, editing, review and publication of scientific papers is carried out better and efficiently in an application system called the electronic scientific journal (ejournal). It can be seen that Management of Scientific Publications evolved and innovated, following changes in Disruption. Director General of Strengthening Research and Development at the Ministry of Research, Technology and Higher Education Muhammad Dimyati said that based on data from ASEAN international publications indexed by Scopus as of April 6, 2018, Indonesia had 5,125 publications. This number is higher than Thailand and Singapore. Unfortunately, there are not many Indonesian researchers, who can penetrate the 100-200 world scientific journals. In terms of Scientific Publication Management, Indonesia is growing and moving forward, following Disrupsi. In this case we can take an outline that in the face of the Disruption Era, we are required to never stop innovating, stop taking shelter under regulation, utilize technology as much as possible, and certainly not easily feel satisfied. The fact is that continuous changes occur. Of course, if we easily feel satisfied, we will always be left behind in this era of change.

\section{References}

[1] Handayani, Indri., Aini, Qurotul., Sari, Novita. (2018). Pemanfaatan Sistem iJC Berbasis OJS Sebagai Media E-Journal Pada STISIP YUPPENTEK. Vol.2, No.2, pp. 94-106. Tangerang, Banten.

[2] A JayashreeR, ChristyA. Enhanced User-Driven Ranking System with Splay Tree. TELKOMNIKA Telecommunication Computing Electronics and Control), 2018; 16(2).

[3] Bornmann L, Daniel HD. The state of $h$ index research. EMBO reports, 2009; 10(1):26.

[4] WahyudinD, Aziz WDI, Rahmatullah S, Irwansyah FS, Sugilar H, Maylawati DSA, Suhendi HY. Productivity Ranking Scientific Publication Ranking Based on the Google Scholar h-Index (In Bahasa: Analisis Ranking Produktivitas Publikasi IImiah Berbasis h-Index Google Scholar). 2018.

[5] Dimyati, Muhammad. (2018). PEDOMAN AKREDITASI JURNAL ILMIAH. pp. 1-218. Jakarta, Indonesia.

[6] Thakral S, BansalD, Chakarvarti SK. Implementation and Analysis of Reversible logic Based Arithmetic Logic Unit. TELKOMNIKA Telecommunication Computing Electronics and Control.2016; 14(4): 1292-1298.

[7] Zhang CT. The h'-index, effectively improving the h-index based on the citation distribution. PloS one, 2013; 8(4): e59912

[8] Simaremare, Yosua P.W., Pribadi Apol S., \& Wibowo Radityo P. (2013). Perancangan dan Pembuatan Aplikasi Manajemen Publikasi IImiah Berbasis Online pada Jurnal SISFO. Vol. 2, No. 3, pp. 470-475. Surabaya, Indonesia.

[9] Harzing AWK, Van der WalR. Google Scholar as a new source for citation analysis. Ethics in science and environmental politics, 2008; 8(1): 61-73.

[10] Lukman. (2015). MANAJEMEN PENGELOLAAN JURNAL: EVALUASI KESIAPAN SESUAI AKREDITASI NASIONAL. pp. 1-17. Jakarta, Indonesia.

[11] Amalia, Ika. 2016 Perancangan Viewboard GO+ Sebagai Penunjang Laporan Pembayaran Mahasiswa Pada Perguruan Tinggi.

[12] Rahardja, Untung., Lutfiani, Ninda., Lestari, Arini Dewi., Manurung, Edward B.P. (2019). Inovasi Perguruan Tinggi Raharja Dalam Era Disruptif Menggunakan Metodologi iLearning. Vol.13, No.1, pp. 23-34 Tangerang, Banten.

[13] J, Cowls and J, Bright. 2017. International Hyperlinks In Online News Media. 
[14] Rahardja, U., Harahap, E. P., \& Suciani, A. (2017). Media Viewboard Sebagai Klasifikasi Jumlah Surat Keputusan Online Pada Perguruan Tinggi. Technomedia Journal, 2(1), 67-79.

[15] Almada-Lobo, F. (2016). The Industry 4.0 revolution and the future of manufacturing execution systems (MES). Journal of Innovation Management, 3(4), 16-21.

[16] Brettel, M., Friederichsen, N., Keller, M., \& Rosenberg, M. (2014). How virtualization, decentralization and network building change the manufacturing landscape: An Industry 4.0 Perspective. International Journal of Mechanical, Industrial Science and Engineering, 8(1), 37-44.

[17] Juditha, C. (2013). Akurasi Berita dalam Jurnalisme Online (Kasus Dugaan Korupsi Mahkamah Konstitusi di Portal Berita Detiknews). Pekommas, 16(3).

[18] Thwari, Amit S. dan Dr. S.E Yedey.2016.Study Of Codeigniter Technology. International Journal of Research in Computer \& Information Technology. Vol. 2 No.2.

[19] Lee, Sunguk. 2012. Unified Modeling Language (UML) for Database Systems and Computer Applications. International Journal of Database Theory and Application. Vol.5 No.1.

[20] Soemantri, Nursam. 2015 Perancangan Viewboard iDuHelp! Menggunakan Bootstrap Sebagai Penunjang Laporan Perfoma iDuHelp! Online Pada Perguruan Tinggi.

[21] Karalli, Rusol., Joyce Tipton Doina Dumitru., Lisa Scholz., Santhi Masilamani. 2015. Development of a metrics dashboard for monitoring involvement in the Drug Pricing Program, s.a. American Journal of Health-System Pharmacy September 1, 2015 vol. 72 no. 17 1489-1495.

[22] Jensen HW. Realistic image synthesis using photon mapping. AK Peters/CRC Press.2001.

[23] Tee KS, Javahar YSH, Saim H, Zakaria WNW, Khialdin SBM, Isa H, Soon CF. A Portable Insole Pressure Mapping System. TELKOMNIKA Telecommunication Computing Electronics and Control.2017; 15(4).), 113-124. 